\title{
Discussing treatment strategies for acute mechanical intestinal obstruction caused by phytobezoar: A single-center retrospective study
}

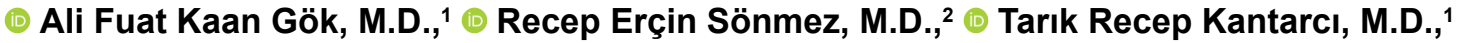

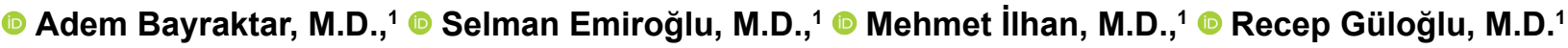

${ }^{1}$ Department of General Surgery, İstanbul University İstanbul Faculty of Medicine, İstanbul-Turkey

${ }^{2}$ Department of General Surgery, İstanbul Medeniyet University Faculty of Medicine, İstanbul-Turkey

\begin{abstract}
BACKGROUND: This study aims to discuss management strategies regarding phytobezoar induced ileus based upon clinical results.

METHODS: In the present study, between December 2012 and December 2018, a total of 25 patients who were diagnosed with phytobezoar were evaluated retrospectively. Patients who had acute mechanical intestinal obstruction due to phytobezoars at different segments of gastrointestinal (Gl) tract were included in this study. The clinical data (such as clinical findings, laboratory results, radiological evaluations, treatment methods) of the patients were examined.
\end{abstract}

RESULTS: Twenty five patients were included in this study. Of the 25 patients, 13 were women (52\%). The median age was 60 (3I-84) years, and the overall median length of the stay was 7 (2-28) days. Previous abdominal surgery had been recorded for I 3 patients (72\%). Two patients (8\%) were followed up conservatively, whereas $20(80 \%)$ patients had needed surgical intervention. One (4\%) patient underwent surgery for distal ileal obstruction due to the pieces of bezoar that crumbled with previous endoscopic intervention. Three of the patients had complications, such as surgical site infection, wound dehiscence and paralytic ileus in the postoperative period. There were no differences between milking and gastrotomy/enterotomy groups according to the length of stay and postoperative complications. One patient died on the $13^{\text {th }}$ postoperative day due to multi-organ failure. The mortality rate was $4 \%$.

CONCLUSION: Phytobezoars, which are common with many other different surgical entities, can be located at any segment of the gastrointestinal tract and may cause obstruction, strangulation and/or even perforation. Contrast-enhanced CT scan must be performed in case of suspicion and to rule out any other causes of acute mechanical intestinal obstruction. Conservative and endoscopic procedures may be useful for selected patients, but the surgical treatment may be needed for the vast majority of the patients with phytobezoar. The surgery is safe for phytobezoar if the enterotomy site is chosen wisely.

Keywords: Ileus; non-operative management; phytobezoar; surgery.

\section{INTRODUCTION}

Bezoars, although present mostly at the gastroduodenal segment, is defined as the formation of a mass in non-absorbable materials at any part of the gastrointestinal (GI) tract. ${ }^{[1]}$ This formation may occur within weeks, months or even years depending on etiology and patients may present with nonspecific physical findings, such as colic abdominal pain, dis- tention, nausea, which occur mostly due to an obstruction in the $\mathrm{Gl}$ tract. ${ }^{[2]}$ Because of these features that can mimic many other surgical entities, the differential diagnosis should be made accordingly.

Bezoars are often present in the form of 'trichobezoar, phytobezoar, pharmacobezoar or lactobezoar'. Besides occurring mostly due to endocrine disorders like hypothyroidism

Cite this article as: Gök AFK, Sönmez RE, Kantarcı TR, Bayraktar A, Emiroğlu S, İlhan M, et al. Discussing treatment strategies for acute mechanical intestinal obstruction caused by phytobezoar: A single-center retrospective study. Ulus Travma Acil Cerrahi Derg 2019;25:503-509.

Address for correspondence: Ali Fuat Kaan Gök, M.D.

İstanbul Üniversitesi İstanbul Tıp Fakültesi, Genel Cerrahi Anabilim Dalı, Çapa, İstanbul, Turkey

Tel: +90 212 - 4142000 / 32319 E-mail: afkgok@gmail.com

Ulus Travma Acil Cerrahi Derg 2019;25(5):503-509 DOI: 10.14744/tjtes.2019.24557 Submitted: 25.02.2019 Accepted: 05.08.2019 Online: 22.08.2019

Copyright 2019 Turkish Association of Trauma and Emergency Surgery 
(e.g. autoimmune, post-thyroidectomy), previous abdominal surgery (e.g. peptic ulcer surgery, tumor surgery, bariatric surgery), Gl motility disorders (e.g. chronic intestinal pseudoobstruction, neurogenic motility disorders), they are more frequent in patients having eating disorders or in patients who are diabetic. ${ }^{[3]}$

Different treatment methods have been described regarding its management. Although the approach may differ according to the clinical status of the patient, mostly used regimens, such as $\mathrm{N}$-acetylcysteine (NAC), papain, metoclopramide, cellulase enzyme preparations, 'diet Coca-Cola ${ }^{\mathrm{TM}}$ ', are preferred in the first stage, and surgical interventions are chosen for cases where endoscopic intervention and conservative treatment fails. ${ }^{[4]}$

\section{MATERIALS AND METHODS}

\section{Study Design}

Medical records of the patients were evaluated retrospectively between December 2012 and December 2018. The patients with acute mechanical intestinal obstruction (AMIO) caused by phytobezoar were included in this study. Patient characteristics, including age, admission white blood cell count (WBC), history of previous abdominal surgery, any known comorbidities, drug usage, history of consuming 'persimmon' specifically, previous history of hospital admission due to phytobezoar, diagnostic modalities, endoscopic intervention, and surgical procedure reports were obtained from the medical records.

\section{Diagnosis of Bezoar}

Abdominal examination was performed according to the patient's anamnesis. After that, routine blood tests for AMIO were carried out, such as whole blood count, biochemistry tests (glucose, creatinine, electrolyte values, C- reactive protein), and the plain abdominal X-rays were obtained. A contrast-enhanced (oral/iv/rectal) abdominal computerized tomography (CT) scan was performed to rule out the other reasons for AMIO. Intravenous (IV) contrast-enhanced abdominal CT scan was performed after confirming creatinine values less than $1.4 \mathrm{mg} / \mathrm{dL}$. The CT scan was performed with oral and rectal water-soluble contrast only if the creatinine level was higher than $1.44 \mathrm{mg} / \mathrm{dL}$. The mass that outlined by the bowel wall and presented internal gas bubbles was considered the characteristic mottled appearance of bezoar (Fig. I). CT scan findings, such as the level of obstruction according to the location of phytobezoar in the Gl tract, any fluid collection, and/or perforation were recorded.

\section{Treatment}

Patients having nausea and abdominal distention were decompressed with nasogastric (NG) catheterization. Oral intake was stopped. Parenteral fluids and proton-pump inhibitors (PPIs) were given. Coca-Cola ${ }^{\mathrm{TM}}(330 \mathrm{~mL} / \mathrm{six}$ times a

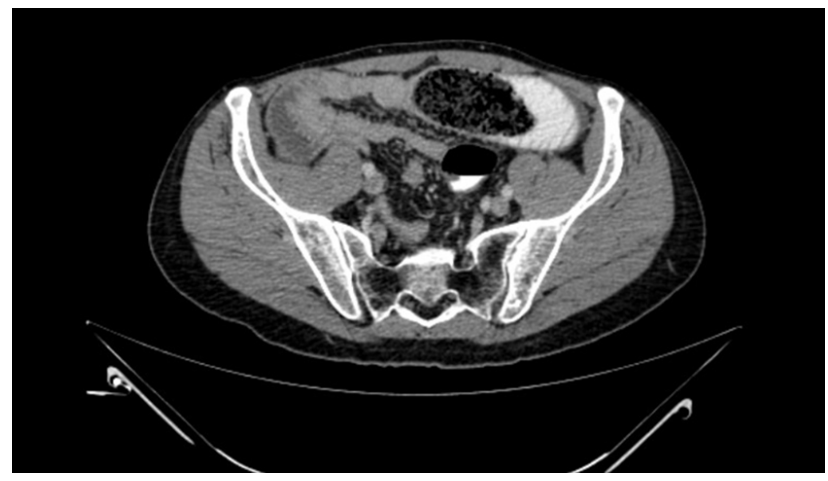

Figure 1. Showing phytobezoar located at jejunoileal segment causing intestinal obstruction.

day) were given for conservative treatment via either oral or NG tube after Gl decompression. Parenteral fluids were ordered according to serum electrolyte levels on the following day of admission.

The physical and laboratory findings recorded according to abdominal examinations were performed routinely every day during hospitalization. Daily plain abdominal X-rays and routine laboratory tests were obtained to monitor the severity of the obstruction. The NG tube was removed, and oral fluid regimen was given when the symptoms of the obstruction began to recover (such as gas outlet and/or defecation, and disappearance of air-fluid levels on the plain abdominal X-ray). The patients who got well with the conservative treatment were discharged for out-patient control.

The patients who did not get well or deteriorated underwent surgery after 72 hours of the conservative treatment. The milking procedure (crumbling the bezoar with fingers gently and milking through the ileocaecal valve without gastrotomy and/or enterotomy) was the first preferred option for the surgical treatment. Gastrotomy and/or enterotomy were performed to remove the bezoar if the milking procedure was failed. The preferred enterotomy site was the collapsed and healthy distal bowel segment after the obstruction to make a safe intestinal repair.

The patients with a bezoar located at the upper Gl tract underwent upper $\mathrm{Gl}$ endoscopic intervention to reduce the size of bezoar and/or to remove the bezoar if possible using an endoscopic snare and/or basket catheter.

\section{Statistical Analysis}

Data analysis was performed using Statistical Software for Social Sciences (SPSS), version 23 for Windows (IBM Corporation, Armonk, New York). The Chi-squared test or Fisher's exact test was used to compare categorical variables. Student's t-test was used to analyze normally distributed variables, and the non-parametric Mann-Whitney $U$ test was used for the analysis of non-normally distributed values. Statistical significance was considered at $\mathrm{p}<0.05$. 
In this study, approval of the local institutional review board was not needed because of the retrospective nature of the present study. Only the patient database was evaluated for study parameters and therefore informed consent was not obtained from the patients.

\section{RESULTS}

Of the 25 patients, $13(52 \%)$ were female, 12 (48\%) were male. The median age was $60(31-84)$ years, and the overall median length of the stay was 7 (2-28) days. Abdominal distention and tenderness were the most common symptoms recorded during the physical examination at the admission $(n=17,68 \%$ ). Median WBC and CRP values found as 10650 $\mu \mathrm{L}$ and $50.4 \mathrm{mg} / \mathrm{L}$, respectively.

The most common comorbidities were diabetes mellitus and dental problems. Thirteen patients (52\%) had previous abdominal surgery. Seven (25\%) patients in this group had a history of gastric surgery (Table I).

A phytobezoar was detected that causes Gl obstruction at the gastroduodenal segment and jejunoileal segment respectively in $8(32 \%)$ and $17(68 \%)$ patients according to radiological evaluations (Fig. I). Two (8\%) patients had multiple bezoars at both gastroduodenal and jejunoileal segments (Fig. 2a, b).

Two patients (8\%) were got well according to physical findings and laboratory tests (decrement of acute phase reactants such as CRP and WBC count) underwent contrast-enhanced CT scan again for control evaluations. The control CT scans showed that phytobezoars which were located at the upper GI tract migrated distally and crumbled into smaller parts, as well as ileus-like findings such as dilated bowel loops, thickening of the bowel wall, findings of mesenchymal heterogenicity which indicated that inflammations were regressed spontaneously unlike the previous CT scan.

Twelve patients (48\%) had a history of 'persimmon' consumption according to their anamnesis. Within this group, five $(20 \%)$ of them had no previous abdominal surgery and any known comorbidity that may cause phytobezoar induced GI tract obstruction (Fig. 3).
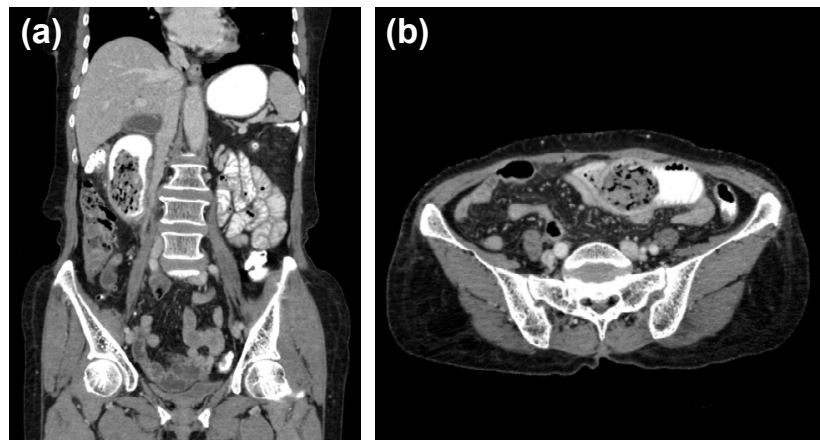

Figure 2. Showing multipl bezoars at both gastroduodenal (a) and jejunoileal segments (b).
Besides, 12 (48\%) patients included in the present study had no history of previous abdominal surgery. Five $(20 \%)$ of them had dental problems, such as denture teeth and/or missing teeth, and four (16\%) of them were being treated for psychiatric disorders.

Table I. Demographic findings

Total ( $\mathbf{n}=\mathbf{2 5}$ )
Gender
Female
Male
Age (years)
I8-40
$40-65$
$>65$
Previous abdominal surgery
Yes
Peptic ulcus
$\quad$ Gastrectomy (distal subtotal or
$\quad$ antrectomy)
$\quad$ BTV + pyloroplasty
$\quad$ BTV + gastroenterostomy
Gastric neuroendocrine tumor
(distal subtotal gastrectomy)
Sigmoid colon tumor (anterior resection)
Hysterectomy
Laparoscopic right nephrectomy
Whipple's procedure
Bezoar

Comorbidities

Diabetes mellitus

Missing teeth or denture teeth

Psychiatric disorders

Ischemic coronary disease

Chronic pulmonary disease

Hypothyroidism

Chronic kidney disease

$13 \quad 52$

$12 \quad 48$

$3 \quad 12$

$13 \quad 52$

936

13

52

6

3

2

I

I

Previous admission for bezoar

Yes

Twice

4

8

No

Persimmon consumption

Yes

$12 \quad 48$

No

$13 \quad 52$ 
Table 2. Type of treatment and complications

\begin{tabular}{|c|c|c|}
\hline Total $(n=25)$ & $\mathbf{n}$ & $\%$ \\
\hline \multicolumn{3}{|l|}{ Conservative } \\
\hline Successful & 2 & 8 \\
\hline Failure & 23 & 92 \\
\hline Endoscopic interventions & II & 44 \\
\hline Successful & 3 & \\
\hline \multicolumn{3}{|l|}{ Number of endoscopies } \\
\hline 3 & 1 & \\
\hline 2 & 1 & \\
\hline I & 1 & \\
\hline Failure & 8 & \\
\hline Surgery & 20 & 80 \\
\hline Milking & II & \\
\hline Gastrotomy & 3 & \\
\hline Enterotomy & 5 & \\
\hline Gastrotomy and enterotomy & 1 & \\
\hline Complications & 5 & 20 \\
\hline Distal ileal obstruction due to the & 1 & \\
\hline \multicolumn{3}{|l|}{ pieces of bezoar that crumbled with } \\
\hline \multicolumn{3}{|l|}{ previous endoscopic intervention } \\
\hline Wound dehiscence & 1 & \\
\hline Superficial surgical site infection & 1 & \\
\hline Postoperative ileus & 1 & \\
\hline Mortality & 1 & 4 \\
\hline
\end{tabular}

Upper Gl endoscopy was performed for II (44\%) patients who had phytobezoars located at the upper GI tract according to CT evaluations. Three of them treated successfully with endoscopic interventions (Fig. 4a-d). Within this group, the surgical intervention was required for eight patients due to lack of clinical improvement despite conservative and endoscopic treatment (Fig. 5). The failure rate of endoscopic treatment was $72 \%$ (Table 2 ).

Twenty (80\%) patients underwent surgery. Of these, II (44\%) patients underwent the milking procedure without gastrotomy and/or enterotomy. Enterotomy was performed for five patients and gastrotomy was performed for three patients. Gastrotomy and enterotomy were performed for only one patient to remove bezoars located at different segments of the GI tract (Table 2). There were no differences between milking and gastrotomy/enterotomy groups according to the length of stay and postoperative complications (Table 3).

One (4\%) patient underwent surgery for distal ileal obstruction due to the pieces of bezoar that crumbled with previous endoscopic intervention. Three patients had complications, such as surgical site infection, wound dehiscence and para-

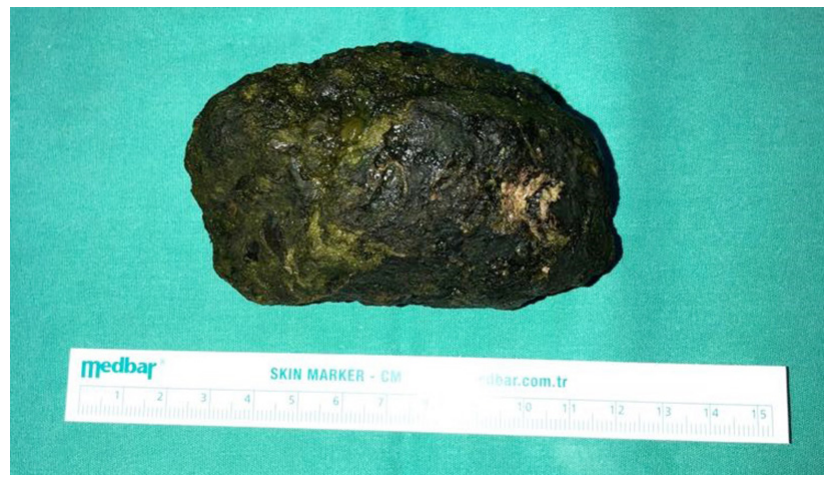

Figure 3. The appearance of 'phytobezoar' reaching $10 \mathrm{~cm}$ long which was taken out by enterotomy.
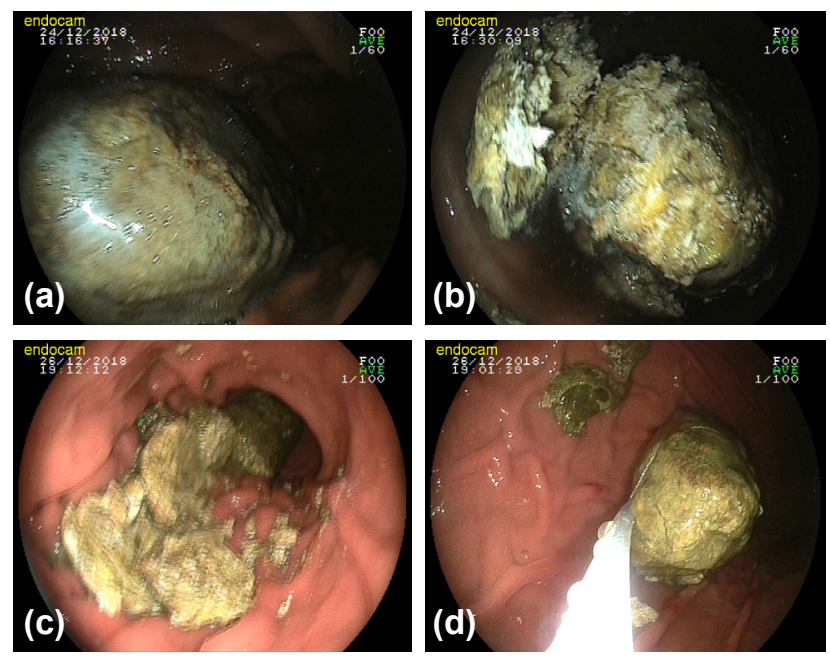

Figure 4. A gastric bezoar case treated successfully with endoscopic intervention. The full size of the bezoar (a), reducing the size of the bezoar with snare and basket catheter (b), Second endoscopic intervention 48 hours later to reduce the size of the size of the bezoar (c), removing the bezoar with a snare (d).

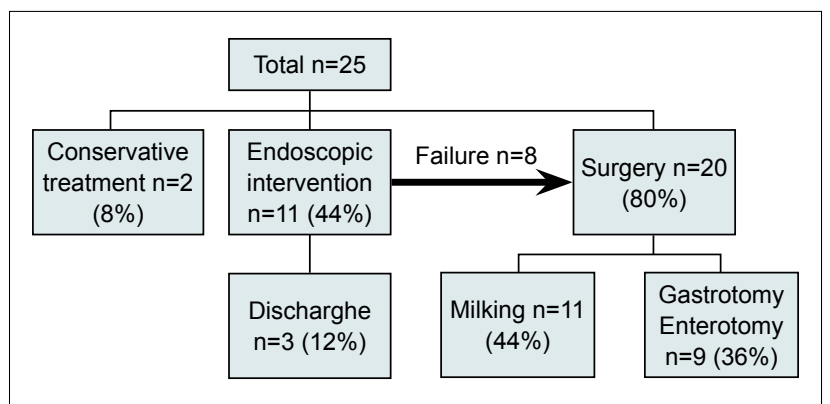

Figure 5. The clinical course of the bezoar cases.

lytic ileus, in the postoperative period. One patient died on the 13th postoperative day due to multi-organ failure. The mortality rate was $4 \%$.

\section{DISCUSSION}

The present study aims to discuss the diagnostic process and treatment options for patients with phytobezoar. The findings from our study showed that the vast majority of patients 
Table 3. Comparing outcomes according to the surgery types

\begin{tabular}{|c|c|c|c|c|}
\hline & $\begin{array}{l}\text { Total } \\
(n=20)\end{array}$ & $\begin{array}{c}\text { Milking } \\
(n=I I, 55 \%)\end{array}$ & $\begin{array}{c}\text { Gastrotomy/enterotomy } \\
(n=9,45 \%)\end{array}$ & $\mathbf{p}$ \\
\hline Length of stay & $10(4-4 I)$ & $10(4-14)$ & $14(5-4 \mid)$ & 0.603 \\
\hline Wound dehiscence & 1 & $0(0 \%)$ & I (II\%) & 0.257 \\
\hline Superficial surgical site infection & 1 & $0(0 \%)$ & I (II\%) & 0.257 \\
\hline Postoperative ileus & I & I (9\%) & $0(0 \%)$ & 0.257 \\
\hline
\end{tabular}

with phytobezoar underwent surgery. Our findings suggest that conservative and endoscopic procedures may be useful for selected patients. Also, our study showed that surgery for phytobezoar is safe if the enterotomy site is chosen carefully. Along with the discovery of etiological factors related to the formation of bezoars, conservative treatment had become to gain more weight progressively beginning from the early 1960s when before that period surgery was the mainstay of treatment. ${ }^{[5-7]}$ By contrast, most of the patients $(80 \%)$ in our study group required surgery.

The first and most important step considering the management of the disease is to make the diagnosis accurately. Detailed physical examination, the assistance of radiological modalities (plain abdominal X-ray and contrast-enhanced CT) and endoscopic procedures are of utmost importance to accomplish accurate diagnosis. ${ }^{[8]}$

The findings of abdominal examination can mimic many different abdominal pathologies as previously mentioned, which mostly include abdominal distention, nausea, vomiting, the absence of $\mathrm{Gl}$ outlet. ${ }^{[9]}$ The patients in the present study had similar complaints.

Certain etiological factors come forward, such as the patients with a history of previous abdominal surgery, especially patients who had gastric surgery before (notably peptic ulcer surgery involving vagotomy+/-pyloroplasty such as Billroth I/ II) related with increased risk of bezoar formation due to deterioration of peristaltism according to recent literature. ${ }^{[10,11]}$ Also, bariatric surgery (such as sleeve gastrectomy, gastric bypass, duodenal switch) and tumor surgery are the other common predisposing factors. ${ }^{[2]}$ Phytobezoars may lead to obstruction, stricture, entero-enteric fistula, bleeding, or perforation within the lumen depending on the level at which it occurs. ${ }^{[13]}$ Seven patients $(28 \%)$ in our study had a history of gastric surgery due to different causes. In the past years, peptic ulcer surgery had given its way to conservative treatments since the use of medical agents, such as proton-pump inhibitors, H2-receptor antagonists, and mucosal barrier-protective agents. ${ }^{[14]}$ Interpretation of our findings is that the long-term results of previously done procedures performed with vagotomy (truncal or selective) had reflected in the present-day with this 'phytobezoar formation'.
Bezoar formation is more common for people having disorders, such as hypothyroidism, diabetes mellitus, chronic idiopathic intestinal pseudo-obstruction, and psychiatric disorders, accompanied by eating disorders due to the disruption of intestinal motility. ${ }^{[15]}$ In recent studies, it has been claimed that absorption and peristalsis are impaired due to an increase in levels of Glucagon-Like Peptide-I (GLP-I) for patients with diabetes mellitus, and it has been accused in the formation of bezoar. ${ }^{[16]}$ In this study, two patients had a history of thyroid hormone replacement due to total thyroidectomy. Also, six patients were diagnosed with diabetes mellitus. It is difficult to claim that these disorders are related in the retrospective evaluation, but the conclusion that can be reached on the basis of the literature is given that these comorbidities may have caused greatly to the formation of phytobezoar. And of course, the control and regular follow-up of these patients with endocrine disorders are of great importance in terms of their impact.

Unlike ingestion of non-nutrient substances, such as metal, hair (also known as Rapunzel Syndrome) in some patients with psychiatric disorders, consumption of high fiber content may also cause phytobezoar formation. ${ }^{[17]}$ Recent studies showed that persimmon consumption is frequently being blamed for phytobezoar occurrence in our region. The persimmon, mostly consumed in the northern region of Turkey, contains protein, fat, carbohydrates, iron, vitamins and high fiber. The high fiber content of persimmon makes it difficult to digest with gastric acid and this could lead to the formation of phytobezoar and obstruction in any part of the gastrointestinal tract in time. ${ }^{[18,19]}$ In our study, 12 (48\%) patients had a history of persimmon consumption recently. In this group, five patients had no predisposing factor, such as previous abdominal surgery or an eating disorder, except the persimmon consumption. Another interesting feature related to one of these patients is the detection of a newly emergent phytobezoar recorded on admission CT scan that disappeared on the control CT scan, which was obtained ten days later. The formation and disappearance of phytobezoar in such a short period of time are very rare according to our research in literature.

Coca-Cola ${ }^{\mathrm{TM}}$ treatment for bezoar cases has been frequently mentioned in recent studies. ${ }^{[20]}$ According to the theory, 
$\mathrm{NaHCO}_{3}$ and $\mathrm{CO}_{2}$ molecules inside the mass cause dissection process that lead to the dissolution of smaller particles. ${ }^{[21,22]}$ On the other hand, it has been published in many scientific reports that these disintegrating small parts can lead to re-obstruction of a distal bowel segment. ${ }^{[23,24]}$ However, it is frequently preferred because of its low cost and simple applicability. ${ }^{[25]}$ We administered the coke either by oral or nasogastric tube. Some patients tolerated this procedure well, and there were no problems recorded, but most of the patients (92\%) underwent additional procedures such as endoscopy and/or surgery according to our study.

In our institution, conservative and minimally invasive approaches are preferred at first stage. Based on CT findings, we performed endoscopic interventions for patients who had phytobezoars located at the upper Gl tract. Successfully endoscopic procedure rate was $28 \%$. In spite of this, we had to perform surgical intervention as a last resort for the patients whose clinical condition did not improve. Twenty $(80 \%)$ patients underwent surgery in our study group. Successful results can be achieved without requiring bowel resection by using the milking method and enterotomy. There was no evidence of a statistically significant negative effect of gastrotomy/enterotomy comparing to the milking procedure only on postoperative complications (Table 3). The key point for surgery without complications is to make enterotomy at the distal and healthy bowel segment. This could make the enterotomy site safer.

In our study, we tried to summarize our institution's experience on patients with phytobezoar, but this study has some limitations, such as small sample size, retrospective design and well not documented physical examination findings.

\section{Conclusion}

Phytobezoars which are common with many other different surgical entities can be located at any segment of the gastrointestinal tract and may cause obstruction, strangulation and/or even perforation. The patients' anamnesis should be taken accurately, including any comorbidities, previous surgery, eating habits, consumption of persimmon. Detailed physical examination and laboratory tests must be performed according to the clinical condition. Contrast-enhanced CT scan must be performed in case of suspicion and to rule out any other causes of acute mechanical intestinal obstruction. Conservative and endoscopic procedures might be useful for selected patients, but the surgical treatment may be needed for the vast majority of the patients with phytobezoar. The surgery is safe for phytobezoar if the enterotomy site is chosen wisely. It must be kept in mind that this study was only conducted on a small group of patients retrospectively. Further prospective studies are needed to determine the best treatment option for patients with phytobezoar.

Conflict of interest: None declared.

\section{REFERENCES}

1. Mihai C, Mihai B, Drug V, Cijevschi Prelipcean C. Gastric bezoars-diagnostic and therapeutic challenges.J Gastrointestin Liver Dis 2013;22:111.

2. Iwamuro M, Okada $H$, Matsueda $K$, Inaba $T$, Kusumoto C, Imagawa $\mathrm{A}$, et al. Review of the diagnosis and management of gastrointestinal bezoars. World J Gastrointest Endosc 2015;7:336-45. [CrossRef]

3. Prieto-Aldape MR, Almaguer-García FI, Figueroa-Jiménez SE, Fernández-Díaz O, Mora-Huerta JA, González-Ojeda A. Relapsing massive metal bezoar: a case report. J Med Case Rep 2009;3:56. [CrossRef]

4. Eng K, Kay M. Gastrointestinal bezoars: history and current treatment paradigms. Gastroenterol Hepatol (N Y) 2012;8:776-8.

5. Chun J, Pochapin M. Gastric Diospyrobezoar Dissolution with Ingestion of Diet Soda and Cellulase Enzyme Supplement. ACG Case Rep J 2017;4:e90. [CrossRef]

6. Ladas SD, Kamberoglou D, Karamanolis G, Vlachogiannakos J, Zouboulis-Vafiadis I. Systematic review: Coca-Cola can effectively dissolve gastric phytobezoars as a first-line treatment. Aliment Pharmacol Ther 2013;37:169-73. [CrossRef]

7. Koulas SG, Zikos N, Charalampous C, Christodoulou K, Sakkas L, Katsamakis N. Management of gastrointestinal bezoars: an analysis of 23 cases. Int Surg 2008;93:95-8.

8. Ho TW, Koh DC. Small-bowel obstruction secondary to bezoar impaction: a diagnostic dilemma. World J Surg 2007;31:1072-8; discussion 1079-80. [CrossRef]

9. Eisenberg RL, Levine MS. Miscellaneous abnormalities of the stomach and duodenum. In: Gore RM, Levine MS, editors. Gastrointestinal Radiology, 3rd ed. Philadelphia, USA: Saunders; 2008: p. 679-706. [CrossRef]

10. Pinto D, Carrodeguas L, Soto F, Lascano C, Cho M, Szomstein S, et al. Gastric bezoar after laparoscopic Roux-en-Y gastric bypass. Obes Surg 2006;16:365-8. [CrossRef]

11. Dirican A, Unal B, Tatli F, Sofotli I, Ozgor D, Piskin T, et al. Surgical treatment of phytobezoars causes acute small intestinal obstruction. Bratisl Lek Listy 2009;110:158-61.

12. Ben-Porat T, Sherf Dagan S, Goldenshluger A, Yuval JB, Elazary R. Gastrointestinal phytobezoar following bariatric surgery: Systematic review. Surg Obes Relat Dis 2016;12:1747-54. [CrossRef]

13. Andrus CH, Ponsky JL. Bezoars: classification, pathophysiology, and treatment. Am J Gastroenterol 1988;83:476-8.

14. Eisner F, Hermann D, Bajaeifer K, Glatzle J, Königsrainer A, Küper MA. Gastric Ulcer Complications after the Introduction of Proton Pump Inhibitors into Clinical Routine: 20-Year Experience. Visc Med 2017;33:221-6. [CrossRef]

15. Sanders MK. Bezoars: from mystical charms to medical and nutritional management. Pract. Gastroenterol 2004;28:37-50.

16. Nauck MA. Glucagon-like peptide 1 (GLP-1) in the treatment of diabetes. Horm Metab Res 2004;36:852-8. [CrossRef]

17. Naik S, Gupta V, Naik S, Rangole A, Chaudhary AK, Jain P, et al. Rapunzel syndrome reviewed and redefined. Dig Surg 2007;24:157-61.

18. Şahin M, Bülbüloğlu E. Fitobezoara Bağlı Mekanik İnce Barsak Obstrüksiyonu: Vaka Takdimi. Turgut Özal Tip Merkezi Dergisi 1996;3:121-3.

19. Ersan Y, Yavuz N, Yüceyar S, Çiçek Y, Ergüney S, Karataş A, et al. Cerrahi tedavi gerektiren mide bezoarları. Cerrahpaşa J Med 2005;36:128-33.

20. Lee HJ, Kang HG, Park SY, Yi CY, Na GJ, Lee TY, et al. Two cases of phytobezoars treated by adminsitration of Coca-Cola by oral route. [Article in Korean]. Korean J Gastroenterol 2006;48:431-3.

21. Lu L, Zhang XF. Gastric Outlet Obstruction-An Unexpected Complication during Coca-Cola Therapy for a Gastric Bezoar: A Case Report and 
Literature Review. Intern Med 2016;55:1085-9. [CrossRef]

22. Ha SS, Lee HS, Jung MK, Jeon SW, Cho CM, Kim SK, et al. Acute intestinal obstruction caused by a persimmon phytobezoar after dissolution therapy with Coca-Cola. Korean J Intern Med 2007;22:300-3. [CrossRef]

23. Yen HH, Chou KC, Soon MS, Chen YY. Electronic clinical challenges and images in GI. Migration of a gastric bezoar. Gastroenterology 2008;134:e1-2. [CrossRef]

24. Chen HW, Chu HC. Migration of gastric bezoars leading to secondary ileus. Intern Med 2011;50:1993-5.

25. Kramer SJ, Pochapin MB. Gastric phytobezoar dissolution with ingestion of diet coke and cellulase. Gastroenterol Hepatol (N Y) 2012;8:7702.

\section{ORİJINAL ÇALIŞMA - ÖZET}

\section{Fitobezoara bağlı akut mekanik intestinal obstrüksiyon için tedavi stratejilerinin} tartışılması: Tek merkezli geriye dönük bir çalışma

Dr. Ali Fuat Kaan Gök, ${ }^{1}$ Dr. Recep Erçin Sönmez, ${ }^{2}$ Dr. Tarık Recep Kantarcı, ${ }^{1}$ Dr. Adem Bayraktar, ${ }^{1}$

Dr. Selman Emiroğlu, ${ }^{1}$ Dr. Mehmet İlhan, ${ }^{1}$ Dr. Recep Güloğlu ${ }^{1}$

${ }^{1}$ İstanbul Üniversitesi İstanbul Tıp Fakültesi, Genel Cerrahi Anabilim Dalı, İstanbul

${ }^{2}$ Istanbul Medeniyet Üniversitesi Tıp Fakültesi, Genel Cerrahi Anabilim Dalı, Istanbul

AMAÇ: Bu çalışmanın temel amacı, fitobezoarın neden olduğuı ileus ile ilgili klinik sonuçlara dayanan tedavi stratejilerini tartışmaktır.

GEREÇ VE YÖNTEM: Aralık 2012 ve Aralık 2018 yılları arasında fitobezoar tanısı alan toplam 25 hasta geriye dönük olarak değerlendirildi. Farklı seviyelerde gastrointestinal (Gl) tıkanıklığa yol açmış fitobezoarlara bağlı akut mekanik bağırsak obstrüksiyonu olan hastalar çalışmaya alındı. Hastaların klinik verileri (klinik bulgular, laboratuvar sonuçları, radyolojik değerlendirmeler, tedavi yöntemleri) değerlendildi.

BULGULAR: Çalışmaya 25 hasta dahil edildi. Yirmi beş hastanın I3'ü kadındı (\%52). Ortanca yaş 60 (3I-84) yıldı ve toplam ortanca kalış süresi yedi (2-28) gündü. On üç hastada (\%72) geçirilmiş abdominal cerrahi olduğu tespit edildi. İki hasta (\%8) konservatif olarak takip edildi, 20 (\%80) hastaya cerrahi müdahale gerekti. Bir hastaya (\%4) önceki endoskopik girişim ile parçalanan bezoar parçaları yüzünden oluşan distal ileal obstrüksiyon nedeniyle cerrahi girişim uygulandı. Ameliyat sonrası dönemde hastaların üçünde cerrahi alan enfeksiyonu, yara ayrılması ve ameliyat sonrası ileus gibi komplikasyonlar geliştiği saptandı. Sadece milking yapılan grup ile gastrotomi/enterotomi grupları arasında hastanede yatış süresi ve ameliyat sonrası komplikasyonlar açısından fark olmadığı saptandı. Bir hasta ameliyat sonrası I3. günde çoklu organ yetersizliği nedeniyle öldü. Mortalite oranı \% 4 olarak saptandı.

TARTIŞMA: Fitobezoar kaynaklı akut mekanik bağırsak tıkanıklığı ile başvuran seçilmiş olgularda konservatif yaklaşım uygulanarak, önemli cerrahi müdahale gerekmeksizin uygun klinik iyileşme sağlanabilir. Ancak konservatif tedaviye yanıt alınamayan olgularda cerrahi tedavi mutlaka göz önünde bulundurulmalıdır. Enterotomi yapılan bağırsak segmentinin dikkatlice seçilmesi güvenli cerrahi için önemlidir.

Anahtar sözcükler: Cerrahi; fitobezoar; ileus; konservatif tedavi.

Ulus Travma Acil Cerrahi Derg 2019;25(5):503-509 doi: I0.14744/tjtes.2019.24557 